\title{
In vitro antibacterial and antioxidant activity of Rosmarinus officinalis
}

\author{
A. K. Milyuhina ${ }^{1}$, L. A. Zabodalova ${ }^{1}, U . K_{\text {Kyzdarbek }}^{1}$, I. R. Romazyaeva ${ }^{2}$, and N. Yu. \\ Klyuchko, ${ }^{2 *}$ \\ ${ }^{1}$ Faculty of Food Biotechnologies and Engineering, ITMO University, Saint-Petersburg, Russia \\ ${ }^{2}$ Faculty of Mechanics and Technology, Kaliningrad State Technical University, Kaliningrad, Russia
}

\begin{abstract}
Rosmarinus officinalis L. is known for its antioxidant and antibacterial properties against a variety of microorganisms. In this work, research has been carried out on pharmacy rosemary. Its antioxidant and antimicrobial properties have been determined. This study showed that the ethanol extract of R. officinalis L. has a pronounced antimicrobial activity against strains of both gram-positive and gram-negative bacteria. The extract also showed good antioxidant activity. Rosemary showed significantly more potent antibacterial activity against $E$. coli. The diameter of the zone of oppression was $17 \mathrm{~mm}$. Thus, Rosemary Pharmaceutical has demonstrated potential as a dietary supplement due to its stronger antibacterial activity.
\end{abstract}

\section{Introduction}

Medicinal rosemary (Rosmarinus officinalis L.) is an evergreen, densely leafy shrub up to 1-1.5 $\mathrm{m}$ high, belongs to the Lamiaceae family. Rosemary is native to the western Mediterranean. It is cultivated all over the world: in Italy, Asia Minor, USA. Rosemary is grown on the southern coast of Crimea and Central Asia.

Rosmarinus officinalis preparations are used mainly in the food industry as flavoring agents, as well as in flavorings and medicines. Rosemary leaves are used as a seasoning and food preservative. Rosemary essential oil exhibits pronounced antibacterial, antifungal, anti-inflammatory, cytostatic, antioxidant properties [1]. Some studies have shown that R. officinalis exhibits antioxidant, antimicrobial activity [2], hepatoprotective [3], and antitumor activity [4].

Rosemary stimulates the immune system. The plant is used for hypotension, general exhaustion. Rosemary has the following medicinal properties: antioxidant, antiinflammatory, choleretic, tonic, wound healing, antidepressant. It also has a softening and antitussive effect on colds.

Much attention in research is paid to rosemary essential oil. It is known to contain cineole, camphor, limonene, borneol, tannins, resins, bitterness, $\alpha$-pinene, borny l acetate, 1,8-cineol [5, 6]. And also, iron, phosphorus, magnesium, sodium, potassium and zinc, which are in the composition of the plant, have a beneficial effect on the immune system of

\footnotetext{
* Corresponding author: natalya.kluchko@klgtu.ru
} 
the human body. Rosemary leaves and shoots also contain flavonoids, rosemary, caffeic, nicotinic, ursolic acids, and amino acids [6].

In a study [7], it was shown that the main component of rosemary essential oil is 1,8-cineole. It exhibits antimicrobial action against microorganisms such as Staphylococcus aureus, Bacillus subtilis, Bacillus pumilis, Salmonella poona, Escherichia coli.

The aim of this study was to evaluate the in vitro antibacterial and antioxidant activity of $R$. officinalis flower extracts.

\section{Materials and methods}

The study used dry crushed Rosmarinus officinalis Horst Company, purchased from a pharmacy.

\subsection{Preparation of culture of microorganisms}

In this study, bacterial strains S. aureus (NCIMB 8625), Enterococcus spp, E. coli (ATCC25922) were used. All bacterial strains were grown and maintained on nutrient agar slants.

\subsection{Determination of antibacterial activity}

The antibacterial activity of Rosemary in different ratios was assessed by the method of discs or diffusion in agar [8] against three bacterial strains. Bacterial strains were first grown on nutrient agar for 24 hours at $37^{\circ} \mathrm{C}$. Then, the bacterial cell suspension $\left(10^{6} \mathrm{CFU} / \mathrm{ml}\right)$ was poured into Petri dishes containing dry nutrient agar. Discs $(5 \mathrm{~mm}$ in diameter) were applied to the surface of inoculated agar and soaked in 50 microliters of rosemary extract. Sodium benzoate, a well-known preservative, was used as a control. The sodium benzoate concentration was $1 \mathrm{~g} / \mathrm{ml}$. Control discs were also impregnated with sodium benzoate solution. All Petri dishes were incubated at $37^{\circ}$ C for 24 hours.

After incubation, antibacterial activity was determined by measuring the diameter of the zone of inhibition in millimeters (mm)

\subsection{Measurement of antioxidant activity}

Antioxidant activity was determined by the FRAP method. The FRAP method (ferric reducing antioxidant power) is based on the registration of a decrease in the concentration of the complex ion of ferric iron - TPTZ (2,4,6-3 (2-pyridyl) -1,3,5-triazine) when interacting with an antioxidant. The binding of $\mathrm{Fe} 2+$ to the ligand creates a very intense dark blue color of the solution. By measuring the optical density, you can find the amount of reduced iron, and correlate it with the amount of antioxidants. Ascorbic acid was used as a reference substance $[9 ; 10]$. All experiments were carried out in three repetitions.

\section{Results and discussion}

\subsection{Antioxidant activity}

Plant material weighing $10 \mathrm{~g}$ was placed in a conical flask with 96\% ethanol. The flask was then placed in a Monowave 300 Microwave Reactor at 850 watts for 30 minutes. After 
filtering the extraction, a basic solution was obtained [11]. Then four samples were prepared according to the following ratios shown in table 1:

Table 1. Ethanol extract of rosemary in different ratios

\begin{tabular}{|c|c|c|}
\hline Ratio & Basic solution & Ethanol 96\% \\
\hline $1: 0$ & $10 \mathrm{ml}$ & $0 \mathrm{ml}$ \\
\hline $1: 1$ & $5 \mathrm{ml}$ & $5 \mathrm{ml}$ \\
\hline $1: 2$ & $3,33 \mathrm{ml}$ & $6,67 \mathrm{ml}$ \\
\hline $1: 3$ & $2,5 \mathrm{ml}$ & $7,5 \mathrm{ml}$ \\
\hline
\end{tabular}

Then, from each sample, $0.1 \mathrm{ml}$ was taken and $3 \mathrm{ml}$ of FRAP reagent was added. After 5 minutes, the absorbance was measured at $\lambda=593 \mathrm{~nm}$. FRAP reagent was used as a reference solution.

Antioxidant activity was determined using the following formulas: $\mathrm{AA}=\frac{\mathrm{A}}{0,134}(\mathrm{mg} / \mathrm{ml})$ where, $\mathrm{A}$ is the absorption of the test samples, 0.134 is the absorption of ascorbic acid (vitamin C).

The results are shown in Table 2 and Figure 1.

Table 2. The results of the study of antioxidant activity

\begin{tabular}{|c|c|c|c|c|}
\hline \multirow{2}{*}{ Raw materials } & Dilution & $\begin{array}{c}\text { Concentration } \\
(\mathrm{mg} / \mathrm{ml})\end{array}$ & Absorption & $\begin{array}{c}\text { The same amount } \\
\text { of ascorbic acid } \\
(\mathrm{mg} / \mathrm{ml})\end{array}$ \\
\hline \multirow{3}{*}{$\begin{array}{c}\text { Rosmarinus } \\
\text { officinalis } L .\end{array}$} & $1: 0$ & 50,0 & 0,511 & 6,350 \\
\cline { 2 - 5 } & $1: 1$ & 25,0 & 0,312 & 4,885 \\
\cline { 2 - 5 } & $1: 2$ & 16,7 & 0,188 & 2,285 \\
\hline
\end{tabular}

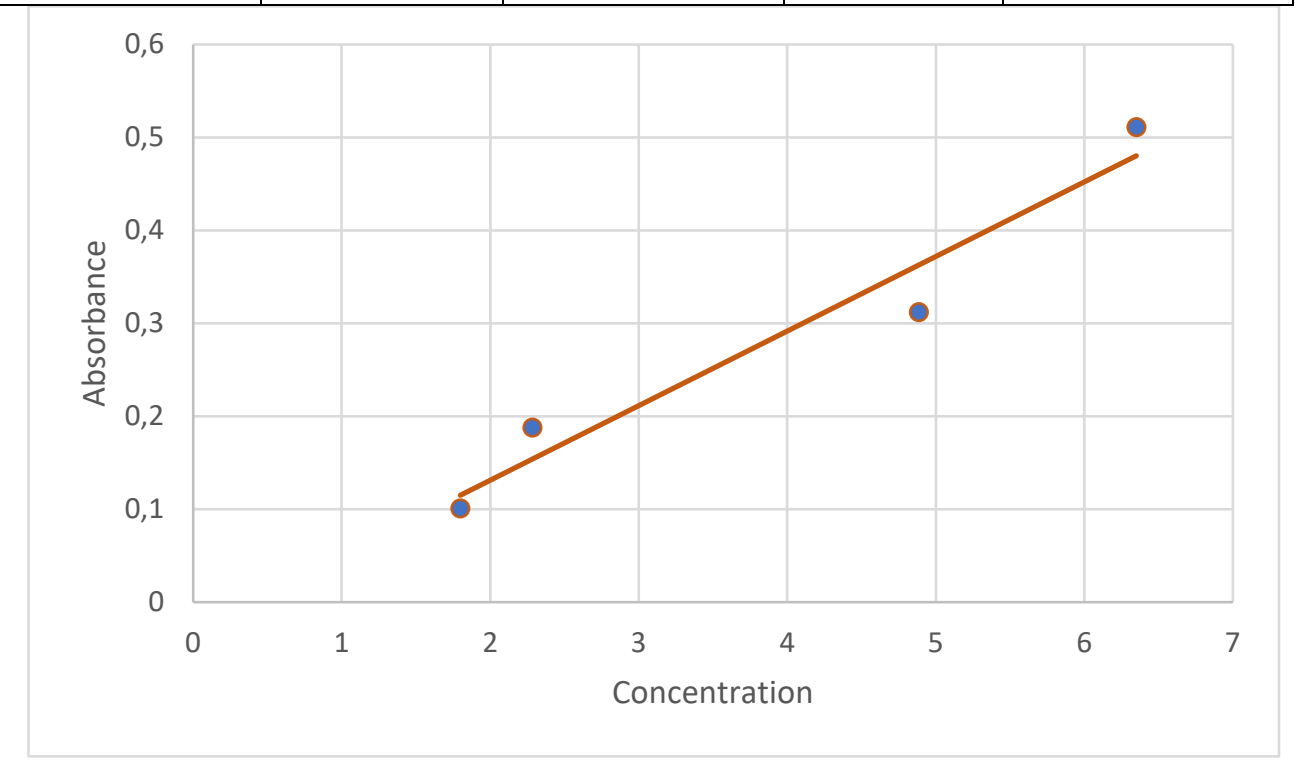

Fig. 1. Results of the study of antioxidant activity 


\subsection{Antimicrobial activity}

The zones of inhibition of microorganisms by rosemary extract were determined by the agar diffusion method [8]. The chemical preservative sodium benzoate was used to control the action of the rosemary extract. After 24 hours of incubation, the diameters of the zones of inhibition were measured for each type of extract (Table 3).

Table 3. Antimicrobial activity of Rosemary in different dilutions (mm)

\begin{tabular}{|c|c|c|c|}
\hline Dilution & S. aureus $(\mathrm{mm})$ & $\begin{array}{c}\text { Enterococcus spp } \\
(\mathrm{mm})\end{array}$ & E. coli $(\mathrm{mm})$ \\
\hline $1: 0$ & $12 \pm 0.2$ & $10 \pm 0.5$ & $17 \pm 0.2$ \\
\hline $1: 1$ & $4.2 \pm 0.2$ & $6.4 \pm 0.5$ & $10 \pm 0.1$ \\
\hline $1: 2$ & $4 \pm 0.2$ & $3 \pm 0.2$ & $5.5 \pm 0.5$ \\
\hline $1: 3$ & $2 \pm 0.5$ & $2.2 \pm 0.2$ & $3 \pm 0.2$ \\
\hline Sodium benzoate & $30 \pm 0.5$ & $28 \pm 0.2$ & $34 \pm 0.5$ \\
\hline
\end{tabular}

The results show that the maximum antimicrobial activity of Rosemary is observed in a ratio of 1:0. With a decrease in the amount of Romzarin in the solution, the antimicrobial activity of the resulting extracts also decreases. However, this data is inferior to the standard chemical preservative sodium benzoate serving as a control. Based on the results obtained, it can be concluded that the extract of $R$. officinalis $L$. has antibacterial activity against all tested bacteria.

According to the data obtained, it can be seen that the antimicrobial activity against gram-positive bacteria was manifested better than against gram-negative ones. This is due to the difference in the structure of the cell membrane of gram-positive and gram-negative bacteria. This study [12] has shown that rosemary essential oil has a destructive effect on the cell membrane of gram-positive bacteria.

The composition of Rosemary and its essential oils includes such components as 1,8cineole, $\alpha$-pinene, camphor, $\beta$-caryophyllene, which exhibit a pronounced antibacterial effect [13 - 18]. Bekir et al. [19] associate the antimicrobial properties of the essential oil of $R$. officinalis $L$. with a large amount of camphor, 1,8-cineole, and $\alpha$-pinene. However, other additional components of the essential oil can also have antimicrobial effects [20].

In the present study, the essential oil of $R$. officinalis $L$. showed good antioxidant activity. These results are consistent with some other studies [21-23]. As Chen et al. [24] reported that $\alpha$-pinene, $\beta$-pinene, and 1,8-cineole have antioxidant activity. In another study [25], due to the presence of antioxidant substances, including 1,8-cineole, $\alpha$-pinene, camphor, borneol, high antioxidant activity was shown.

\section{Conclusion}

This study showed that the ethanol extract of $\mathrm{R}$. officinalis L. has a pronounced antimicrobial activity against strains of both gram-positive and gram-negative bacteria. Rosemary extract has also shown good antioxidant activity.

\section{References}

1. G. Pintore, M. Usai, P. Bradesi et al. Flavor and Fragrance Journal. 17, 15-19 (2002). 
2. B. Bozin, N. Mimica-Dukic, I. Samojlik, E. Jovin J. Agric. Food. Chem, 55, 78797885 (2007)

3. C. Hoefler, J. Fleurentin, F. Mortier, J.M. Pelt, J. Guillemain, J. Ethnopharmacol 19, 133-143 (1987)

4. V.G. Kontogianni, G. Tomic, I. Nikolic, A.A. Nerantzaki, N. Sayyad, S. StosicGrujicic, I. Stojanovic, I.P. Gerothanassis, A.G. Tzakos. Food Chem, 136, 120-129 (2013)

5. B. Bozin, N. Mimica-Dukic, I. Samojlik, E. Jovin, J. Agric. Food Chem, 55, 78797885 (2007)

6. O.Y. Celiktas, E.H. Kocabas, E. Bedir, F.V. Sukan, T. Ozek, K.H.C. Baser Food Chem, 100, 553-559 (2007)

7. P. Satyal, T.H. Jones, E.M. Lopez, R.L. McFeeters, N.A. Ali, I. Mansi, A.G. Al -Kaf, W.N. Setzer, Foods, 6, 20 (2017)

8. H. Miladi, R. B. Slama, D. Mili et al, Natural Science, 5, 729-739 (2013)

9. Celiktas O Y et al Food Chemistry 100(2), 553-559 (2007)

10. S.R. Khasanova, T.I. Plekhanova, D.T. Gashimova, E.Kh. Galiakhmetova, E.A. Klysh Chemistry. Biology, 1, 163-166 (2007)

11. Collection of descriptions of laboratory work on the course "Biological Chemistry", 44, (2006)

12. I.F Abdulin Diagnostics of materials 7(6), 3-13 (2007)

13. Z. Stojanović-Radić, M. Nešić, L. Čomić, N. Radulović Biologica Nyssana, 1, 83-88 (2010)

14. D. Djenane, J. Yangüela, L. Montañés, M. Djerbal, P. Roncalés, Food Control, 22, 1046-1053 (2011)

15. A. Ugur, N. Sarac, M.E. Duru, Nat. Prod. Commun. 4, 579-584 (2009)

16. M. Soković, L.J.L.D. van Griensven, Eur. J. Plant Pathol. 116, 211-224 (2006)

17. C. Koutsoudaki, M. Krsek, A. Rodger, J. Agric. Food Chem. 53, 7681-7685 (2005)

18. A. Kadri, Z. Zarai, A. Bekir, N. Gharsallah, D. Mohamed, R. Gdoura J. Med. Plant Res. 5, 5999-6004 (2011)

19. A. Bekir, I. Chobba, R. Ben Mansour, N. Drira, N. Gharsallah, A. Kadri, J. Appl. Pharm. Sci. 2, 34-39 (2012)

20. A.O. Gill, P. Delaquis, P. Russo, R.A. Holley, Int. J. Food Microbiol. 73, 83-92 (2002)

21. S. Gezici, N. Sekeroglu, A. Kijjoa, Indian J. Pharm. Educ. Res. 51, 498-503(2017)

22. A. Raskovic, I. Milanovic, N. Pavlovic, T. Cebovic, S. Vukmirovic, M. Mikov BMC Complement. Altern. Med. 14, 225 (2014)

23. A.I. Hussain, F. Anwar, S.A. Chatha, A. Jabbar, S. Mahboob, P.S. Nigam, Braz. J. Microbiol. 41, 1070-1078 (2010)

24. C.T. Chen, S.Y. Wang, W. Sciarappa, C.Y. Wang, M.J. Camp J. Agric. Food Chem. 56, 5788-5794 (2008)

25. A.H. Ebrahimabadi, A. Mazoochi, F.J. Kashi, Z. Djafari-Bidgoli, H. Batooli Food Chem. Toxicol. 48, 1371-1376 (2010) 